\title{
Acquiring a 9-millionth book
}

\section{University of California's acquisition of the Aboriginal Port Folio}

by Anthony Bliss

$\mathrm{S}$ ome people are born to shop. At the Bancroft Library, located on the University of California (UC) Berkeley campus, curators are paid to shop. To some this might be a definition of Nirvana, but there are serious responsibilities involved. As an observer of shopping behavior, it has struck me that when you go looking for a specific item with specific characteristics, you rarely find it. On the other hand, when you do not know quite what you want, temptation is everywhere.

In mid-1999, the word spread throughout the Berkeley Libraries that we would soon reach the 9-million-volume mark, and a request for proposals was broadcast. An invitation like this piques the curatorial imagination, and it was not long before Theresa Salazar, curator of the Bancroft Collection, spotted an item in a cata$\log$ and got enthusiastic support from Jack von Euw, Bancroft's pictorial

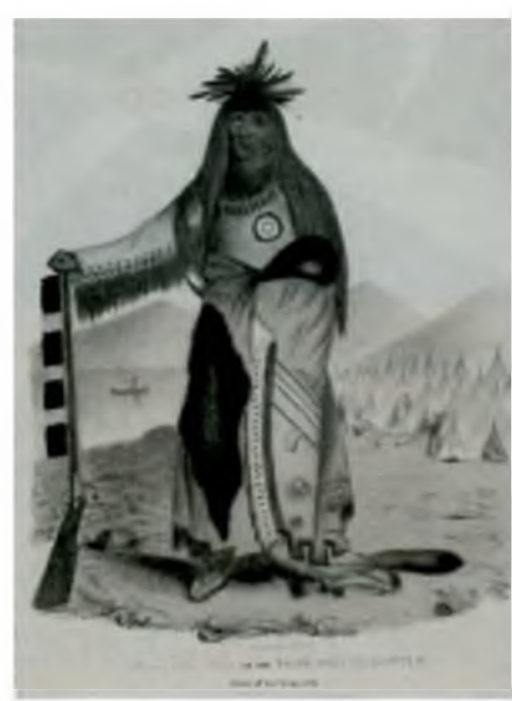

James Otto Lewis's painting of Waa-NaTaa, or the Foremost in Battle, chief of the Sioux tribe. curator. They showed me the listing and I shared their enthusiasm. Before long, the suggestion had reached the top levels of the library and found a solid endorsement.

\section{$A$ race to the presses}

The work in question was James Otro Lewis's Aboriginal Port Folio [sic], a series of handcolored lithographic portraits of American Indian chiefs that was published in 10 monthly parts (each with 8 plates), in 183536 . In the role of official artist, Lewis had accompanied Thomas L. McKenney, superintendent of the Bureau of Indian Affairs, and Lewis Cass, governor of the Michigan Territory, to many treaty councils in the upper Midwest in the 1820 s and early 1830 s. He sketched the Indian chiefs from life, then finished the portraits when he returned to Detroit.

Learning that McKenney planned to publish a Portrait Gallery of

\section{About the author}

Anthony Bliss is curator for the Rare Books Collection at The Bancroft Library at the University of California, Berkeley, e-mail: abliss@library.berkeley.edu 


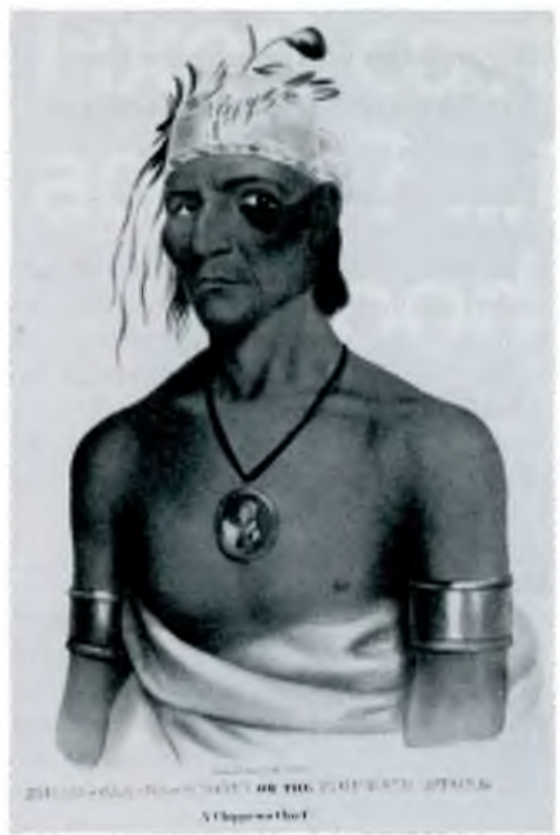

Shing-Gaa-Ba-W'osin, or the Figured Stone, a Chippewa chief.

American Indians, including some of his own work, a resentful Lewis resolved to beat him to the punch. He arranged with the lithographic publishers Lehman and Duval of Philadelphia to begin issuing his portraits in monthly installments. An illustrated prospectus for McKenney's book was just circulating when the first part of Lewis's Aboriginal Port Folio was published in May 1835.

At a pace of one part per month, and at a cost of $\$ 2$ per part, Lewis's work was completed in February 1836. Fewer copies of part 10 (containing plates 73-80) were issued, apparently because of a clispute between Lewis and the publisher. An 11th part, with biographies of the Indian Chiefs, was planned but never published.

The plates in the Aboriginal Pont Folio were issued unbound and unnumbered, so it is impossible today to say which group of eight plates belongs to which part. Early owners of the set had the plates bound in various ways so their order in any particular volume was random. For many years, bibliographers thought that the set was complete with 72 plates and that part 10 had never been distributed to bring the plate count up to 80 .
Lewis was first in the field with his Indian portraits. McKenney's collection, with text by James Hall and retitled The History of the $\mathrm{m}$ dian Tribes of North America, was not available until 1836. Despite, or possibly because of his attention to authentic details, Lewis's work appeared clumsy and amateurish compared to the finely finished and somewhat romanticized images in McKenney and Hall's History. The Aboriginal Port Folio had only one printing; McKenney and Hall went through five folio editions and six octavo editions between 1836 and 1870 .

Our research into the history of the unfortunate Lewis and his work led us to believe that his Aboriginal Port Folio would be an ideal 9-millionth volume for UC. Bancroft already had a fine set of McKenney and Hall, as well as the two other great colorplate books on Native Americans-George Catlin's North American Indian Portfolio of 1844 and the account of Price Maximillian's travels on the plains with illustrations by Karl Bodmer, 1839-41.

\section{Placing the bid}

The only problem was that the item was for sale at auction in New York City. Our librarians could not see it and we did not know how much it would sell for. On top of that, there were two variant copies of the same item being offered, one estimated at more than twice the price of the other. How to decide? I telephoned one of our favorite New York antiquarian book dealers and he agreed to represent UC Berkeley at the October 28 auction sale.

Buying books at a major international auction can be complicated. It is not a good idea to do one's own bidding: only the dealers fully understand the competition and the dynamics of the sale. The dealer's $10 \%$ commission is well earned through advice, counsel, shipping arrangements, and flexible payment schedules.

Our agent went to the auction rooms to inspect both copies of the Lewis Aboriginal Port Folio that were being offered and called me back with his report. The first copy contained all 80 plates, had its title page, and the original wrappers for the first three parts (all that were issued). The Sotheby's estimate was $\$ 40,000-\$ 60,000$. The other copy had 72 plates (lacking the rare tenth part) and no 
title page; the price was estimated at $\$ 15,000$ $\$ 20,000$.

There were damaged plates in both copies: six in the first, three in the second. Their bindings were roughly similar in design and condition. This much we already knew from the printed description, but our agent's analysis was telling: on inspection he found that the 80-plate copy was generally in poorer condition than the other one. Its paper was spotted and browned, and the coloring of the plates was not as well executed as the 72-plate copy.

Armed with this information, we had a curatorial caucus and decided that with our limited funding and for the purposes of Berkeley's collection, the 72-plate copy would very well serve our needs. We found no justification for paying a steep premium for the more complete copy and running the risk of losing it entirely in what promised to be a hotly contested auction. Our strategy then was to put in the strongest bid we could for the second copy to give ourselves the best chance of success. Our mission was to acquire the 9-millionth book: failure was not an option.

The next step was to determine what our bid should be. I got back on the phone with our agent, and we discussed the results of the first part of this sale, the likely competition, the attendance, the interest shown at the prelimi-

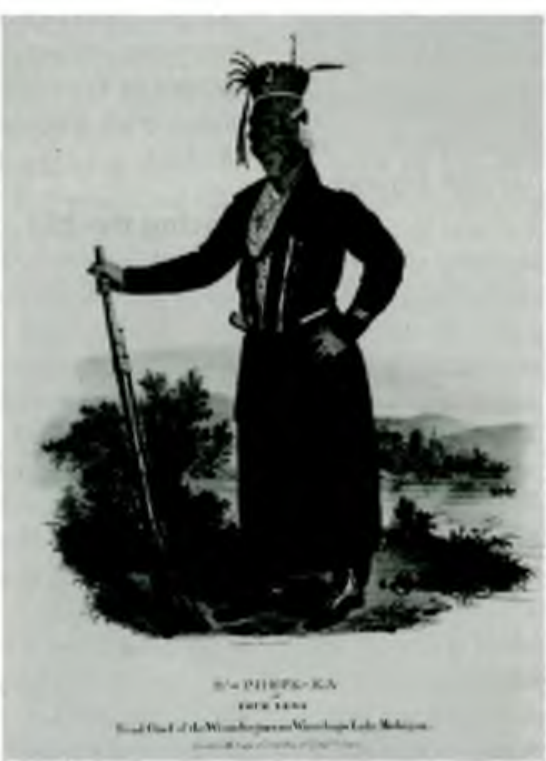

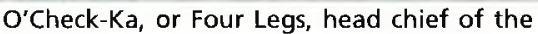
Winnebagoes on Winnebagoes Lake Michigan.

\section{Our mission was to acquire the}

\section{9-millionth book: failure was not an option.}

in the first part of the sale (held five months earlier) and there were no significant changes in the economic situation to suggest that prices would drop. We agreed that a successful bid would have to be significantly over $\$ 75,000$. Working with the Librarian's Office and the Library Development Office, we determined just how high we could go.

\section{The arrival}

The next step was to wait for "The Phone Call" on Thursday afternoon, October 28, 1999. Imagine our joy in learning that the copy we bid on was knocked down to our agent for a mere $\$ 74,000$ ! It was not a steal, but we were much relieved that the price didn't go as high as we feared. It almost looked like a bargain. The 80-plate copy sold for $\$ 145,500$, more than we could have paid.

The next wait was for the package to arrive from New York. After all, none of us had ever actually seen this item. When it arrived a few days later, wonderfully packed and fully insured, we looked it over in great detail, comparing what we nary viewing, and our estimates of the strength of the current rare book market. The estimate of $\$ 15,000-\$ 25,000$ was obviously set low so that potential bidders would not be frightened off.

My own rule of thumb, developed over the years, is that if you really, really want an item, you should be prepared to pay at least triple the high estimate. In this case, the agent and I both felt that a bid of $\$ 75,000$ might not be enough. Prices had been very strong saw with the auction house description and our agent's report.

My first reaction was that either Lewis or the lithographer was not a great artist. The details in the plates-costumes, ornament, weapons-were wonderful, but the portrayal of the figures did seem crude (perhaps I'd seen too much of McKenney and Hall). Despite this quibble, there is something fascinating about these images. They are not

(continued on page 936) 
should disseminate scholarly research and facilitate growth in ways that support the profession. They should continually assess the professional development needs of librarians, offering opportunities for learning in venues and modes that are accessible to career librarians.

\section{Responsibilities of academic institutions}

Through enlightened self-interest, academic institutions should appreciate the importance of-and materially support-professional development for academic librarians. Colleges and universities should demonstrate their commitment to personal mastery and continuous learning, e.g., through financial support, ad- ministrative leave, and/or flexible work schedules for academic librarians engaged in learning activities. They should also measure, recognize and reward exceptional individual and team performance. Institutions have a further responsibility to create, sponsor or offer learning events for their professional staff.

\section{Note}

1. Being Fluent with Information Technology (http://www.nap.edu/books/030906399X/ html/) (1999), Executive Summary, p. 4. Produced by the National Research Council's Commission on Physical Sciences, Mathematics, and Applications. Print edition available from $\mathrm{Na}$ tional Academy Press, Washington, D.C.
("Acquiring a 9-milliontb book" continued from page 892)

overworked and romanticized, they project sense of immediacy that is almost unnerving.

We were all very pleased with the $A b$ original Port Folio, but it clearly needed conservation work. We consulted with Gillian Boal and Nancy Harris in the Library's Conservation Laboratory. Boal would have to deal with repairing the binding and Harris would have to fix the tears in three plates that had been clumsily mended with adhesive tape, as well as some other less difficult problems. Working together, we laid out a plan of conservation work and a timetable for its completion.

The Aboriginal Port Folio had its first public viewing on Cal Day, April 15, and was very much admired. This fall it was prominently featured in the exhibition "Images of Native Americans" in the Bancroft Gallery and runs from September to early December. It's displayed in company with McKenney and Hall, Catlin, Bodmer, and a wealth of other depictions of Native Americans.

\section{Applications/nominations invited for C\&RL editor}

Applications and nominations are invited for the position of editor of College \& Research Libranies ( $C \in R D$ ), the bimonthly, scholarly research journal of the Association of College and Research Libraries (ACRL). The editor is appointed for a three-year term, which may be renewed for an additional three years. Applicants must be a member of ALA and ACRL. Qualifications inclucle professional experience in academic libraries, a record of scholarly publication, editing experience, an ability to meet publication deadlines, an understanding of the scholarly communication process, and a broad knowledge of the issues confronting academic libraries.

Some funding for editorial assistance and travel to relevant conferences is available, and there is a small honorarium for the editor.
Appointment will be made by the ACRL Board of Directors at the 2001 Annual Conference upon the recommendation of the search committee and of the ACRL Publications Committee. The incoming editor will serve a one-year internship with the current editor before assuming full responsibility for $G G R L$ in July 2002.

Nominations or resumes and letters of application, including the names of three references, should be sent to:

C\&RL Search Committee

c/o Hugh Thompson, Director of Publications ACRL

50 East Huron Street

Chicago, IL 60611

hthompson@ala.org

The deadline for receipt of applications is December 6, 2000.

Finalists will be interviewed at the Midwinter Meeting in January 2001. 